\title{
Genetic Mechanisms Mediating Kisspeptin Regulation of GnRH gene Expression
}

\author{
Horacio J. Novaira, Doris Fadoju, Daniel Diaczok, and Sally Radovick \\ Department of Pediatrics, Division of Endocrinology, Johns Hopkins University School of Medicine, Baltimore, Maryland 21287
}

Kisspeptins (Kiss) have been shown to be key components in the regulation of gonadotropin-releasing hormone (GnRH) secretion. In vitro studies have demonstrated an increase in $\mathrm{GnRH}$ gene expression by Kiss suggesting regulation of GnRH at both the secretory and pretranslational levels. Here, we define genetic mechanisms that mediate Kiss action on target gene expression. In vitro, sequential deletions of the mouse $\mathrm{GnRH}(\mathrm{mGnRH})$ gene promoter fused to the luciferase (LUC) reporter gene localized at kisspeptin-response element (KsRE) between -3446 and -2806 bp of the $\mathrm{mGnRH}$ gene. In vivo, transgenic mice bearing sequential deletions of the $\mathrm{mGnRH}$ gene promoter linked to the LUC reporter localized an identical KsRE. To define the mechanism of regulation, Kiss was first shown to induce nucleosome-depleted DNA within the KsRE, and a potential binding site for the transcription factor, Otx-2, was revealed. Furthermore, increased Otx-2 mRNA, protein, and binding to the KsRE after Kiss treatment were demonstrated. In conclusion, this work identified elements in GnRH-neuronal cell lines and in transgenic mice that mediate positive regulation of GnRH by Kiss. In addition, we show for the first time that Otx-2 is regulated by Kiss, and plays a role in mediating the transcriptional response of $\mathrm{mGnRH}$ gene.

\section{Introduction}

The GnRH neurons play a critical central role in the regulation of pubertal development and reproduction, hence, the central and peripheral signals and their molecular mechanisms that regulate these cells are important to elucidate.

Most recently, the physiological control of the reproductive axis was advanced by the identification of the essential role of kisspeptin (Kiss), the peptide product of the KiSS-1 gene, and its receptor, G-protein-coupled receptor 54 (GPR54), in the neuroendocrine regulation of reproduction (de Roux et al., 2003; Seminara et al., 2003). Investigations by many laboratories over the last years have led to the general concept that Kiss-secreting neurons activate GnRH neurons (Roa et al., 2008a; Xu et al., 2011) to advance the complex process of puberty. Furthermore, inactivating mutations of the human GPR54 gene are linked to hypogonadotropic hypogonadism and an absence of puberty (de Roux et al., 2003; Seminara et al., 2003).

The Kiss-GPR54 signaling pathway has also been implicated in normal reproductive cycling in females (Dungan et al., 2006;

\footnotetext{
Received May 21, 2012; revised Sept. 13, 2012; accepted 0ct. 7, 2012.

Author contributions: H.J.N. and S.R. designed research; H.J.N., D.F., and D.D. performed research; H.J.N. analyzed data; H.J.N. and S.R. wrote the paper.

This research was supported by the Eunice Kennedy Shriver National Institute of Child Health and Human Development-National Institutes of Health through cooperative agreement (U54 HD 933067; The Baltimore-Chicago Center for Reproductive Research) as part of the Specialized Cooperative Centers Program in Reproduction and Infertility Research, R01 HD370246, and through cooperative agreement (partnership U01HD066432) as part of the Cooperative Partnerships to Promote Workforce Diversity in the Reproductive Sciences Program. We thank Dr. Pamela Mellon for kindly providing the GT1-7 cell line.

The authors declare no competing financial interests.

D. Fadoju's present address: Pediatric Endocrinologist, Department of Pediatric Endocrinology and Diabetes, Emory-Children's Center, 2015 Uppergate Drive NE, Atlanta, GA 30322-1015.

Correspondence should be addressed to Dr. Horacio Novaira, 600 North Wolfe Street, Baltimore MD 21287. E-mail:hnovair1@jhmi.edu.

DOI:10.1523/JNEUROSCI.2438-12.2012

Copyright $\odot 2012$ the authors $\quad 0270-6474 / 12 / 3217391-10 \$ 15.00 / 0$
}

Seminara et al., 2006; Lapatto et al., 2007). Increased GnRH secretion is observed also in adult animals treated with Kiss (Pielecka-Fortuna et al., 2008; Roa et al., 2008b).

Studies of the role of Kiss on the GnRH neuron have largely focused on cellular secretion of GnRH (Navarro et al., 2005; Gottsch et al., 2006; Roa et al., 2008b). More recent studies, however, have related GnRH gene expression to secretion in response to Kiss stimulation (Jacobi et al., 2007; Novaira et al., 2009). In a previous report, we documented in GnRHsecreting neuronal cell lines (GT1-7 and GN11 cells) (Mellon et al., 1990; Radovick et al., 1991) an increase in GnRH secretion and GnRH mRNA levels with Kiss treatment in a doseand time-dependent manner (Novaira et al., 2009). These data suggest that Kiss affects GnRH expression at both the secretory and pretranslational level.

In addition, the GnRH promoter has been characterized in several previous studies. In vitro experiments have identified several transcription factors (TFs) that interact with $\mathrm{GnRH}$ promoter regions to regulate human, rat, and mouse $\mathrm{GnRH}$ expression (Kelley et al., 2000; Wolfe et al., 2002; Rave-Harel et al., 2005). Furthermore, epigenetic mechanisms have been shown to control GnRH gene expression providing an additional level of regulation that could be involved in the developmental and mature function of GnRH neurons (Kurian et al., 2010; Gan et al., 2012).

In the present studies both GnRH-expressing cell lines and transgenic mice were used as models to explore the molecular mechanisms that regulate GnRH expression by Kiss. The aim of this work was to determine cis-acting GnRH promoter elements, TFs, and chromatin modifications involved in Kiss signaling in GnRH neurons. A kisspeptin-response element (KsRE) located between -3446 and -2806 bp in GnRH-neuronal cell lines and in transgenic mice was identified. Furthermore, we show for the 
first time that Otx-2 is regulated by Kiss and may mediate the transcriptional response of the mouse $\mathrm{GnRH}(\mathrm{mGnRH})$ gene.

\section{Materials and Methods}

Cell culture. GN11 cells were grown in DMEM (Mediatech) supplemented with 7\% fetal bovine serum (FBS) and 3\% newborn calf serum (Hyclone) and $25 \mathrm{~mm}$ glucose, $5 \mathrm{~mm}$ L-glutamine, $100 \mathrm{U} / \mathrm{ml}$ penicillin, and $100 \mu \mathrm{g} / \mathrm{ml}$ streptomycin (Invitrogen) in an atmosphere with $5 \%$ $\mathrm{CO}_{2}$ at $37^{\circ} \mathrm{C}$. GT1-7 cells were grown in a similar manner, except supplemented with $10 \%$ heat-inactivated FBS. Cells were placed in media supplemented with $10 \%$ dextran and charcoal-stripped serum 24 h before treatment. Cells were treated with kisspeptin-10 (EMD Biosciences) at final concentrations of $10^{-9} \mathrm{M}$ for $0.5,1,2$, and $4 \mathrm{~h}$ for TF mRNA and protein evaluation. Fifteen and 45 min of treatment with kisspeptin-10 was used for chromatin immunoprecipitation assay (ChIP) and formaldehyde-assisted isolation of regulatory elements (FAIRE) assays. Control wells were exposed in parallel to vehicle and are referred to as nontreated groups (NT).

Construction of the $m G n R H$ promoter-luciferase DNA plasmids. A GnRH promoter-luciferase construct containing -3446 to +23 bp of the $\mathrm{mGnRH}$ promoter fused to pSV0aL $\Delta 5^{\prime}$ luciferase $(-3446 /+23 \mathrm{mGnRH}-\mathrm{LUC})$ was kindly provided by Dr. Donald B. DeFranco (University of Pittsburgh, Pittsburgh, PA). This $-3446 /+23 \mathrm{mGnRH}-\mathrm{LUC}$ was used for transfection experiments in GT1-7 and GN11 cells and to obtain the sequential deletions of the $\mathrm{mGnRH}$ promoter to be ligated in the pA3LUC reporter vector. The $-2806 /+23$ bp mGnRH-LUC construct was previously described in Novaira et al., 2011, and the $-2078 /+23$ and $-1005 /+23$ bp mGnRH-LUC constructs in Kim et al., 2002.The $-1750 /+23$ and $-587 /+23$ bp mGnRH-luciferase DNA constructs were previously constructed as a HindIII fragments using PCR and the $-3446 /+23$ mGnRH-LUC construct as template. PCR was performed in a thermocycler (Gene-Amp PCR System 9600; PerkinElmer), and reaction mixtures contained $5 \mathrm{U}$ Taq polymerase (DisplayTaq; Display Systems Biotech) and $0.5 \mathrm{~mm}$ deoxynucleotide triphosphates. The PCR products were restriction enzyme digested with HindIII and ligated into a HindIII linearized, alkaline phosphatase (Roche Molecular Biochemicals) dephosphorylated pA3LUC reporter vector (Maxwell et al., 1989; Wood et al., 1989). Orientation was checked by sequencing constructs using a primer annealing to the $5^{\prime}$ end of the luciferase gene.

Transient transfection and cell culture. Transient transfections were performed in GT1-7 and GN11 cell lines. Cells were maintained as described above (see Cell culture). Cells were grown and transfected at $40-60 \%$ confluency. Total DNA was kept constant, and nonspecific effects of viral promoters were controlled using the respective empty pSV0aL $\Delta 5^{\prime}$ luciferase or the empty pA3LUC vectors for each experiment. Luciferase activities in relative light units (RLUs) were measured at the next day of transfection after $4 \mathrm{~h}$ of kisspeptin treatment using the Lumat LB 9507 (Berthold Technologies). Transient transfections were performed in six-well tissue culture plates using a Lipofectamine-plus technique (Invitrogen). A total of $1 \mu \mathrm{g}$ of sequential deletions of $\mathrm{mGnRH}$ promoter fused to the luciferase reporter gene was transfected. Transfections were performed in triplicate for each condition within a single experiment, and experiments were repeated at least three times using different plasmid preparations of each construct. The luciferase activity was measured and absolute RLUs were represented as SEM of representative experiments.

Generation of $m G n R H$ promoter-luciferase mice. Transgenic animals were constructed by the University of Chicago Transgenic Facility by pronuclear injection. Briefly, different DNA constructs containing sequential deletions of the $\mathrm{mGnRH}$ promoter fused to the LUC reporter gene were used to generate several $\mathrm{mGnRH}$-LUC transgenic mice lines. Fertilized mouse oocytes from CD-1 mice were injected with different purified linear mGnRH-LUC DNA fragments. The resulting embryos were transferred into pseudopregnant foster mothers. Transgenic animals were identified with Southern blot analysis as described previously (Wolfe et al., 1996). Briefly, DNA was isolated from tail snips, restriction enzyme digested with EcoRI, and separated with gel electrophoresis. DNA was then transferred to GeneScreen Plus hybridization transfer membrane (NEN). A ${ }^{32} \mathrm{P}$-labeled $1.2 \mathrm{~kb}$ probe for luciferase was used to
Table 1. Sequence of nucleotides

\begin{tabular}{|c|c|}
\hline Primers & DNA sequences \\
\hline qRT-PCR GnRH sense & 5' CCCTTTGACTTTCACATCC $3^{\prime}$ \\
\hline qRT-PCR GnRH antisense & 5' GGGTTCTGCCATTTGATCCAC 3' \\
\hline qRT-PCR 0t×2 sense & $\begin{array}{l}\text { 5'-GCAGAGGTCCTATCCCATGA-3' } \\
\text { (Larder and Mellon, 2009) }\end{array}$ \\
\hline qRT-PCR 0tx2 antisense & $\begin{array}{l}\text { 5'-CTGGGTGGAAAGAGAAGCTG-3' } \\
\text { (Larder and Mellon, 2009) }\end{array}$ \\
\hline qRT-PCR $18 \mathrm{~S}$ sense & 5'-TGGTTGATCCTGCCAGTAG-3' \\
\hline qRT-PCR $18 \mathrm{~S}$ antisense & $5^{\prime}$-CGACCAAAGGAACCATAACT- $3^{\prime}$ \\
\hline 0tx-2 mutant sense & 5'-GCGAGAATTACCGGCGCCAAAGAACTTTTTCG-3' \\
\hline 0tx-2 mutant antisense & 5'-GCTTTTTCAAGAAACCGCGGCCATTAAGAGCG-3' \\
\hline
\end{tabular}

0 tx- 2 binding site at the KsRE

$(-3005 /-3000 \mathrm{bp})$

Sense

Antisense

5'-CAGAGCTGATGGAAACCACA-3'

$5^{\prime}$-AGGAAACCACACCCAACAAG-3'

Otx-2 binding site at the nKsRE $(-2418 /-2413 \mathrm{bp})$

Sense

Antisense

5'-GGCTTGATTATAGCCACCAGGAAAGG-3'

5'-GACATGCCACTCTCCTGA-3'

0tx-2 binding site at the NSE

$(-319 /-252$ bp)

Sense

Antisense

Negative control primers $(-1858 /-1567 \mathrm{bp})$

Sense

Antisense

5'-TCCCTGTGAGTTTTTCAGTGTG-3'

5'-GCAGCACAGCCCATAGTCTT-3'

5-'TGAGATGAACAGCCCACAAA-3'

5'-TGCTCAGTCCTCATGACAGG-3'

Mutated sequences are underlined.

detect transgenic animals that incorporated the luciferase transgene (Kim et al., 2002). For identification of luciferase-expressing transgenic lines, neonatal brains were removed from pups, homogenized, and assayed for the mGnRH-LUC transgene as described below.

Assay of $m G n R H$-luciferase transgene. Adult female and male transgenic LUC mice were housed at the Johns Hopkins Animal facility. All animal studies were approved by the Johns Hopkins Institutional Animal Care Committee. Female mice were cycled and treated with saline solution (control group) or with $1 \mathrm{nmol}$ Kiss intraperitoneally after reaching the diestrus phase of the reproductive cycle. After $4 \mathrm{~h}$ of the injection, the hypothalamus of males and females was harvested and LUC activity was measured in RLUs. Briefly, from adult mice, the olfactory and hypothalamic tissue was dissected in a single fragment consisting of tissue from $1 \mathrm{~mm}$ caudal to the mammillary bodies, 1 $\mathrm{mm}$ laterally beyond the lateral aspect of the median eminence, and 3 $\mathrm{mm}$ dorsally. Tissues were placed in $1 \mathrm{ml}$ of lysis buffer $(25 \mathrm{~mm}$ glycylglycine, $15 \mathrm{~mm} \mathrm{MgSO}_{4}, 4$ mм EGTA, $1 \%$ Triton X-100, and 1 mM dithiothreitol; DTT), and homogenized with a Polytron tissue homogenizer (Brinkmann Instruments). The homogenates were centrifuged at $3000 \mathrm{~g}$ for $10 \mathrm{~min}$ and the supernatants were assayed for luciferase activity. Luciferase activities were assayed using a Lumat LB 9507 luminometer (Berthold Systems). Samples were injected with $100 \mu \mathrm{l}$ of $0.75 \mathrm{~mm}$ luciferin (Invitrogen), dissolved in lysis buffer, and $100 \mu$ lassay buffer ( $25 \mathrm{~mm}$ glycylglycine, $15 \mathrm{~mm} \mathrm{MgSO}_{4}, 4 \mathrm{~mm}$ EGTA, $15 \mathrm{~mm} \mathrm{KPO}_{4}, 3 \mathrm{~mm}$ DTT, and $3 \mathrm{~mm} \mathrm{ATP}$ ) and luminescence were measured for $20 \mathrm{~s}$ as RLUs. Because the background RLU (the RLU measured with lysis buffer alone) varied from day to day, we corrected for the background in each experiment. On each day, the luciferase activity was measured in several samples of lysis buffer alone and averaged to obtain a background RLU level for the day. This background value is subtracted from the measured tissue RLU to give a corrected RLU. The corrected RLU reflected the luciferase activity of the tissue.

FAIRE. Genomic isolation of active regulatory elements was detected by FAIRE. GT1-7 and GN11 cells were cultured as described previously and then treated with kisspeptin for 15 and $45 \mathrm{~min}$ in a $10 \mathrm{~cm}$ plate. FAIRE was performed following the methods described in Giresi and 


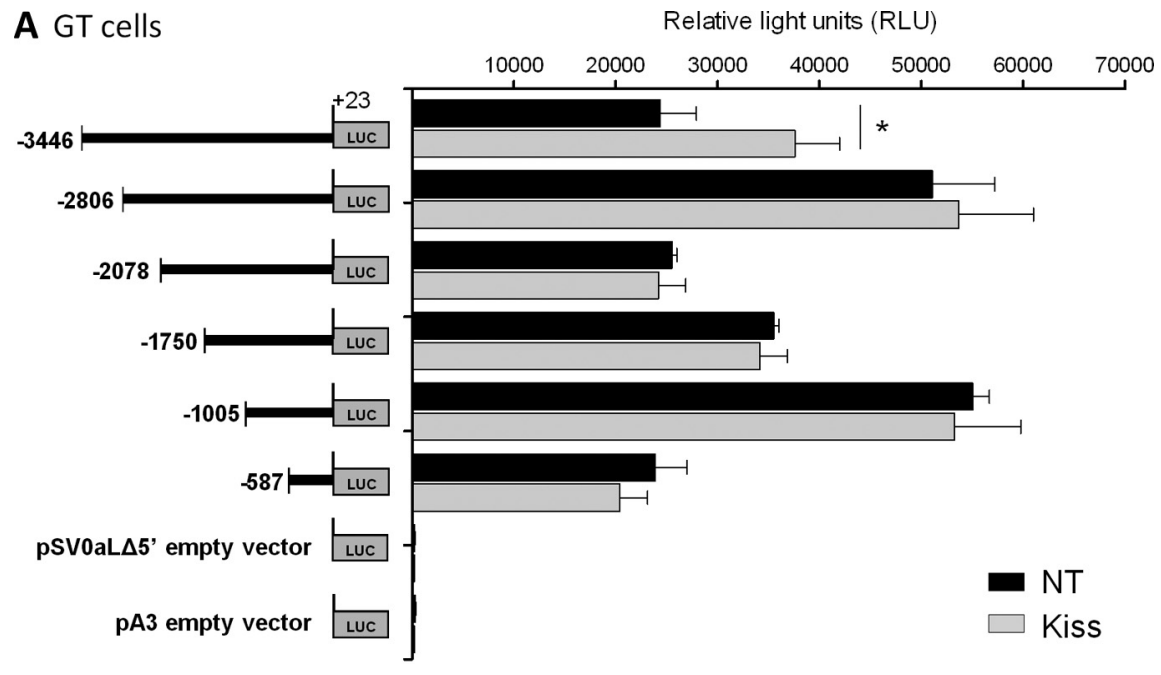

B GN cells

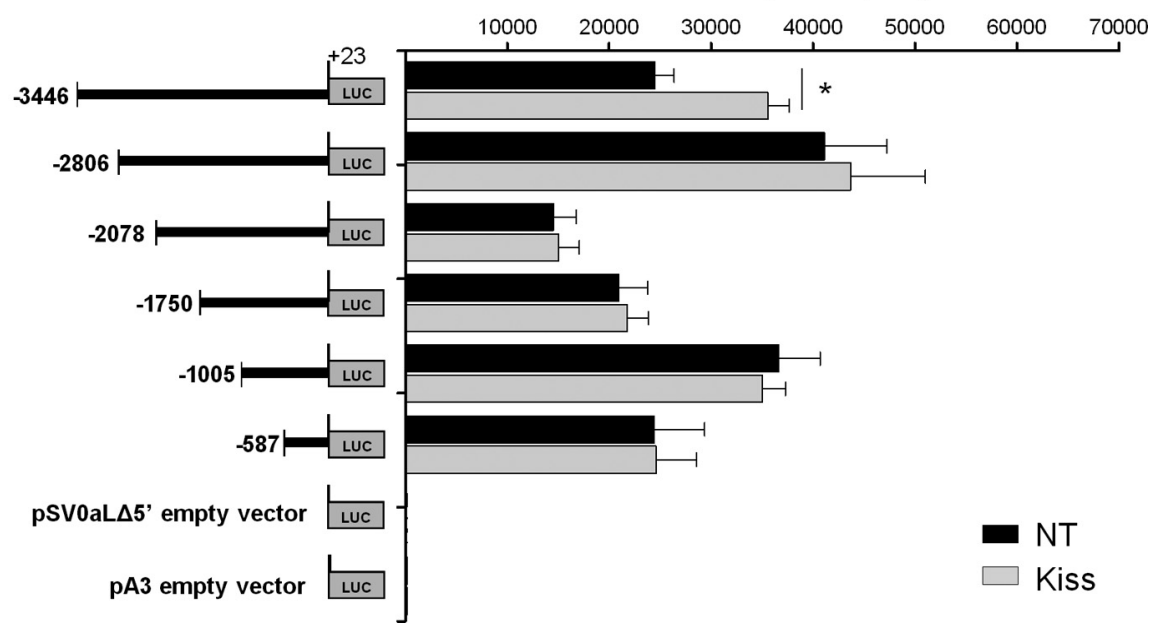

Figure 1. LUC expression in GT1-7 (A) and GN11 (B) cell lines transfected with sequential deletions of the mGnRH promoter fused to the LUC reporter gene. LUC expression was measured as RLUs in NT cells and treated with $10^{-9} \mathrm{M}$ Kiss for $4 \mathrm{~h}(n=3-4$, $p \leq 0.05)$. Asterisks indicate significant differences.

Lieb, 2009. Briefly, after treatment, cells were fixed with $1 \%$ formaldehyde in growth medium for $1 \mathrm{~min}$ at room temperature. After cell and nuclear lysis, the cross-linked DNA was sheared to $\sim 100-1000 \mathrm{bp}$ lengths by sonication on ice in a Branson Sonifier 250-A (five pulses of $10 \mathrm{~s}$ long bursts at power output 3; duty cycle, 50\%). Double DNA Phe$\mathrm{nol} /$ chloroform extraction was performed and RNAase treatment was made. The genomic regions of nucleosome-depleted DNA preferentially segregated into aqueous phase were then mapped back by semiquantitative PCR and quantitative real-time PCR (qRT-PCR) using primers specific to the KsRE, non-KsRE (nKsRE) in the GnRH enhancer (GnRHen), neuron-specific element (NSE), and control elements shown in Table 1. Mouse FSH- $\beta$ (Coss et al., 2004) and $\beta$-actin promoters (Huh et al., 2007) were used as negative and positive controls for nucleosomedepleted DNA, respectively.

ChIP. ChIP assay was performed using the ChIP-IT Express kit (Active Motif) following the manufacturer's instructions. Briefly, GT1-7 and GN11 cells were cultured as described previously and then treated with kisspeptin for 15 and $45 \mathrm{~min}$. Cells were fixed with $1 \%$ formaldehyde in growth medium for $10 \mathrm{~min}$ at room temperature. After cell and nuclear lysis, the cross-linked DNA was sheared to $\sim 200-1500$ bp lengths by sonication on ice in a Branson Sonifier 250-A (three pulses of $10 \mathrm{~s}$ long bursts at power output 3; duty cycle, $50 \%$ ). The sheared cross-linked chromatin was immunoprecipitated (IP) in dilution buffer and incubated overnight at $4^{\circ} \mathrm{C}$ with $15 \mu \mathrm{l}$ of anti-OTX2 antiserum generated in rabbits immunized with the peptide SCPAATPRKQRRERT (residues 37-51) (Diaczok et al., 2008) or $3 \mu \mathrm{g}$ of normal mouse IgG (sc-2025; Santa Cruz Biotechnology) as a negative control. Protein $G$ magnetic beads $(25 \mu \mathrm{l})$ were added to the samples to collect the immune complexes. After washing the beads, protein-DNA complexes were eluted and reverse cross-linked at $95^{\circ} \mathrm{C}$ for $15 \mathrm{~min}$ by incubation in ChIP elution buffer and then treated with proteinase $\mathrm{K}$. After treatment of the genomic DNA with proteinase $\mathrm{K}$ stop solution it was used immediately in quantitative PCR or stored at $-20^{\circ} \mathrm{C}$. The input DNA (an aliquot of the sheared chromatin, not subjected to immunoprecipitation, but reverse cross-linked) was diluted to $10 \%$ and used to validate the performance of different primer pairs designed to amplify the KsRE, nKsRE in the GnRHen, NSE, and the control elements in the GnRH promoter (Table 1).

$q R T-P C R$. RNA was isolated from both cells types and hypothalamic tissues using the TRIzol Reagent (Invitrogen) according to the protocol provided by the supplier. Two micrograms of RNA was reverse transcribed using the iScript cDNA kit (Bio-Rad). qRT-PCR was performed in duplicate using the SyberGreen MasterMix (Bio-Rad) and the ICycler quantitative PCR machine (Bio-Rad Laboratories). Specific primer sequences for GnRH, Otx-2, and $18 \mathrm{~S}$ were used (Table 1). To determine PCR efficiency, a 10-fold serial dilution of cDNA was performed as previously described (Wong and Medrano, 2005). PCR conditions were optimized to generate $>95 \%$ PCR efficiency and only those reactions with between 95 and 105\% efficiency were included in subsequent analyses. Relative differences in cDNA concentration between baseline and experimental conditions were then calculated using the comparative threshold cycle $\left(C_{\mathrm{t}}\right)$ method (Bustin et al., 2005). Briefly, for each sample, a $\Delta C_{\mathrm{t}}$ was calculated to normalize for the internal control using the equation: $\Delta C_{\mathrm{t}}=$ $C_{\mathrm{t}}$ (gene) $-C_{\mathrm{t}}(18 \mathrm{~S})$. To obtain differences between experimental and control conditions, $\Delta \Delta C_{\mathrm{t}}$ was calculated: $\Delta C_{\mathrm{t}}($ sample $)-$ $\Delta C_{\mathrm{t}}$ (control). Relative mRNA levels were then calculated using the equation fold difference $=2^{\Delta \Delta C \mathrm{t}}$.

Western blot analysis. Western blot analysis was performed for OTX-2 protein evaluation in GT1-7 and GN11 cells. Briefly, cellular protein lysates were obtained using cell lysis buffer (\#9803; Cell Signaling Technology) and then $10 \mu \mathrm{g}$ total protein was separated on $10 \%$ SDS/polyacrylamide gels. Proteins were transferred to Protran nitrocellulose membrane (Whatman $\mathrm{GmbH}$ ) in Tris/glycine transfer buffer. The membranes were blocked for $1 \mathrm{~h}$ with $5 \%$ nonfat milk in Tris-buffered saline containing $0.05 \%$ Tween 20 (TTBS) at room temperature and then were incubated overnight with anti-OTX2 antiserum generated in rabbits immunized with the peptide SCPAATPRKQRRERT (residues 37-51) (Diaczok et al., 2008), and with a rabbit polyclonal $\beta$-actin antibody (\#4967; Cell Signaling Technology) as an experimental control. The membranes were washed three times for $10 \mathrm{~min}$ with TTBS and incubated for $1 \mathrm{~h}$ at room temperature with goat anti-rabbit IgG-horseradish peroxidase conjugate secondary antibody (\#172-1019; Bio-Rad). After washing, the blots were visualized using ECL Prime Western blotting detection system (GE Healthcare).

The density of the bands corresponding to the expected size of the protein was analyzed by Quantity One Software for Windows version 4.6 (Bio-Rad Laboratories). 
Site-directed mutagenesis. The QuikChange Site-Directed Mutagenesis XL Kit (Stratagene) was used to introduce mutations into the KsRE in the $-3446 \mathrm{mGnRH}-\mathrm{LUC}$ promoter construct per the manufacturer's instructions. The sequences of the Otx-2 consensus binding site was changed to eliminate Otx-2 binding to the $\mathrm{mGnRH}$ gene promoter using primers shown in Table 1. The TTAT sequences, at -3005 to $-3002 \mathrm{bp}$, were mutated to CCGC, introducing a SacII restriction enzyme site, and generating the -3446 Otx-2 mutant (MUT) LUC. The Otx-2 MUT LUC construct contains mutations in the Otx-2 binding site in the context of the -3446 mGnRH-LUC reporter construct. The presence of the mutations was confirmed both by restriction enzyme digest and sequencing analysis.

Generation of GnRH neuron-specific Otx-2 knock-out mice. GnRH neuron-specific Otx-2 knock-out (KO) (GnRH-Otx-2KO) mice were previously generated and their reproductive competence were published by Diaczok et al., 2011. Briefly, GnRH-Otx$2 \mathrm{KO}$ was created using a mouse line in which the first exon of Otx-2 was flanked by loxP sites and in which cell-specific expression of Cre recombinase under the control of the GnRH promoter causes a loss of Otx- 2 expression (Tian et al., 2002). These mice were crossed with GnRH-Cre mice to specifically target the loxP site recombination to the GnRH neurons of the hypothalamus (Kim et al., 2007; Wolfe et al., 2008).

Adult male GnRH-Otx-2KO mice were housed at the Johns Hopkins Animal facility. All animal studies were approved by the Johns Hopkins Institutional Animal Care Committee. Male mice were treated with saline solution (control group) or with $1 \mathrm{nmol} \mathrm{Kiss} \mathrm{intraperitoneally.} \mathrm{After}$ 20 min of the injection, the hypothalamus of males was harvested and qRT-PCR was performed as described above.

Statistical analysis. Statistical significance was assessed by one-way ANOVA followed by the Newman-Keuls multiple-comparison tests. We used an unpaired Student's $t$ test to compare the secretion levels of GnRH between groups treated with kisspeptin-10 and vehicle. All results are expressed as mean \pm SEM and $p \leq 0.05$ assigned as significant using the GraphPad Prism 4 software.

\section{Results}

Kiss treatment in GT1-7 and GN11 cells indentified an in vitro KsRE located between -3446 and -2806 bp on the mGnRH promoter

GT1-7 and GN11 cells transfected with sequential deletions of the $\mathrm{mGnRH}$ promoter fused to the luciferase reporter gene were treated with $10^{-9} \mathrm{M}$ Kiss for $4 \mathrm{~h}$. Kiss treatment in GT1-7 cells containing the element between -3446 and +23 bp of the $\mathrm{mGnRH}$ promoter had measured LUC activity of 37,600 \pm 4374 RLUs, while the nontreated group had LUC activity of 24,397 \pm 3513 RLU. This represents a 1.6-fold increase in LUC activity in GT1-7 cells after Kiss treatment $(n=3-4, p \leq 0.05$; Fig. $1 A)$. GN11 cells treated with Kiss had measured LUC activity of $35,549 \pm 2089$ RLU, while nontreated cells had 24,492 \pm 1885 RLU, representing a 1.5-fold increase in LUC activity in GN11 cells after Kiss treatment $(n=3-4, p \leq 0.05$; Fig. $1 B)$. No changes in LUC activity were observed in cells transfected with $-2806 \mathrm{bp}$ or more proximal segments of the GnRH promoter. These data suggest a KsRE located within the region between -3446 to -2806 bp of the $\mathrm{mGnRH}$ promoter.
Relative light units (RLU)

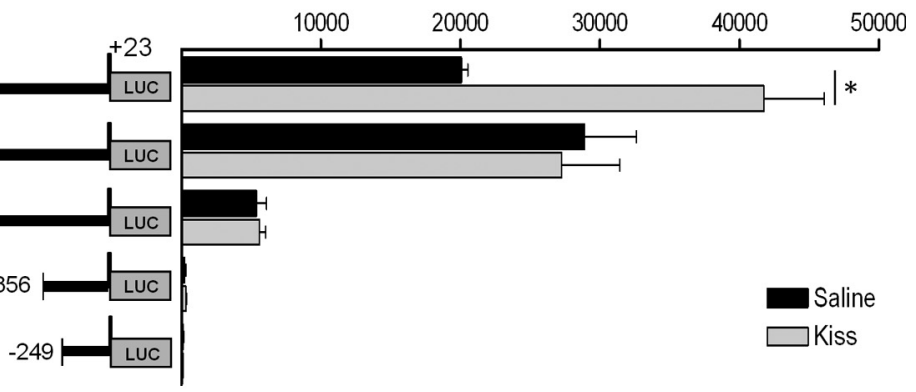

Relative light units (RLU)

B Male LUC mice

$\underset{1}{20000} \quad 30000 \quad 40000 \quad 50000$

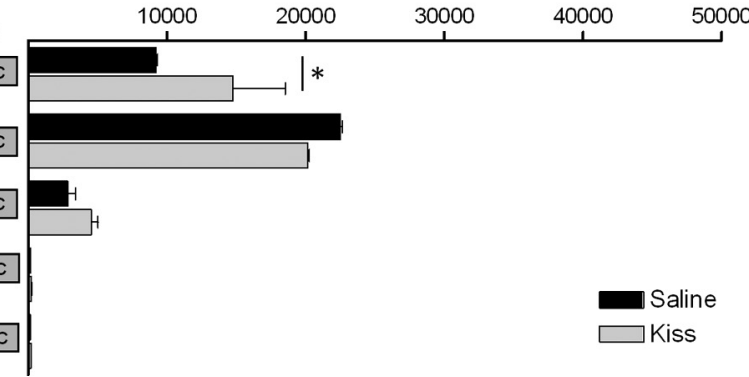

Figure 2. LUCactivity in hypothalamus of transgenic mice bearing sequential deletions of the $\mathrm{G}$ GRH promoter fused to the LUC reporter gene. LUC expression is measured as RLUs in miceinjected intraperitoneally with saline or $1 \mathrm{nmol}$ Kissinjection intraperitoneally.A, Female $(n=3-5, p \leq$ $0.05)$ and ( $\boldsymbol{B})$ male transgenic mice $(n=3-4, p \leq 0.05)$. Asterisks indicate significant differences.

\section{A KsRE is identified between -3446 and -2806 bp of the $\mathrm{mGnRH}$ promoter after Kiss injection in GnRH-LUC transgenic mice}

Since luciferase expression is under the control of the $\mathrm{mGnRH}$ promoter, $\mathrm{mGnRH}$ promoter activity can be detected and quantitated by measuring luciferase activity in tissue homogenates from transgenic mice containing sequential deletions of the $\mathrm{mGnRH}$ promoter fused to the LUC reporter gene. Transgenic mice were treated with saline solution or $1 \mathrm{nmol}$ Kiss intraperitoneally and $4 \mathrm{~h}$ after the injection, and brain homogenates were assayed. Female control mice bearing the $-3446 /+23$ bp GnRH promoter LUC transgene had measured LUC activity of 20,074 \pm 457 RLU, while the group treated with Kiss had LUC activity of $41,772 \pm 4296 \mathrm{RLU}$. This represent a twofold $(n=3-5, p \leq 0.05$; Fig. 2A) increase in LUC after Kiss treatment in female mice. Brain homogenates from male control mice had LUC activity of $14,766 \pm 3792$ RLU and 22,533 \pm 121 RLU after Kiss treatment, representing a 1.6 -fold increases $(n=3-4, p \leq 0.05$; Fig. $2 B)$. No statistical changes in LUC activities were observed in female or male transgenic mice bearing the -2806 bp or shorter segments of the GnRH promoter. As in the in vitro studies, a KsRE was located between -3446 and -2806 bp of the mGnRH gene. In addition, in both female and male mice the presence of the enhancer element between -3446 and -2078 bp of the $\mathrm{mGnRH}$ promoter was noted as previously described (Kim et al., 2002; 2007) (Fig. 2A,B).

Kiss increases genomic isolation of active regulatory elements at the Otx-2 binding site within the KsRE of the mGnRH promoter

Quantities of PCR products corresponding to GnRH regulatory elements (KsRE, nKsRE in the GnRHen, NSE, and the control elements in the GnRH promoter) were measured and compared with $\beta$-actin and $\mathrm{FSH}-\beta$ promoter genes that correspond to ac- 

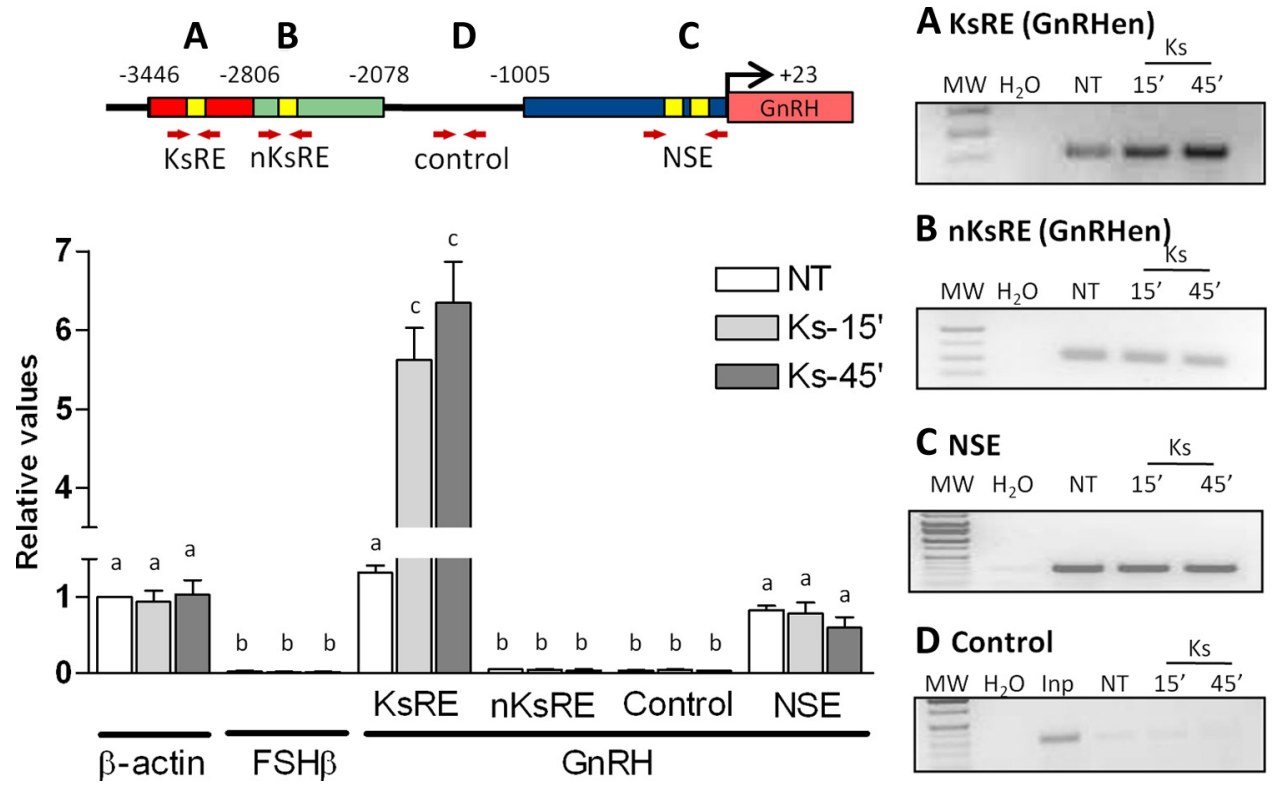

Figure 3. FAIREshowing a time course Kiss response. Kiss induces opening of chromatin within the KsRE of the GnRH promoter in GT1-7 cells.A,FAIREanalysisat the KsREcontained between - 3446 and -2806 bp on the mGnRH promoter (red shading). B, FAIRE at thenKsRE contained between - 2418 and - 2413 bp on the mGnRH promoter located in the GnRHen (green shading). C, FAIRE performed at the NSE (blue shading) of the $m G n R H$ promoter. $D$, Control of nonactive chromatin of the GnRH promoter contained between -1858 and -1567 bp (black line). Graphic representation of the means \pm SE of relative DNA (qRT-PCR) graphed as fold increase of levels relative to NT group. Cells were treated with $10^{-9} \mathrm{M}$ Kiss for 15 and $45 \mathrm{~min}(n=3, p \leq 0.05)$. There is no statistical difference between groups with the same letters.
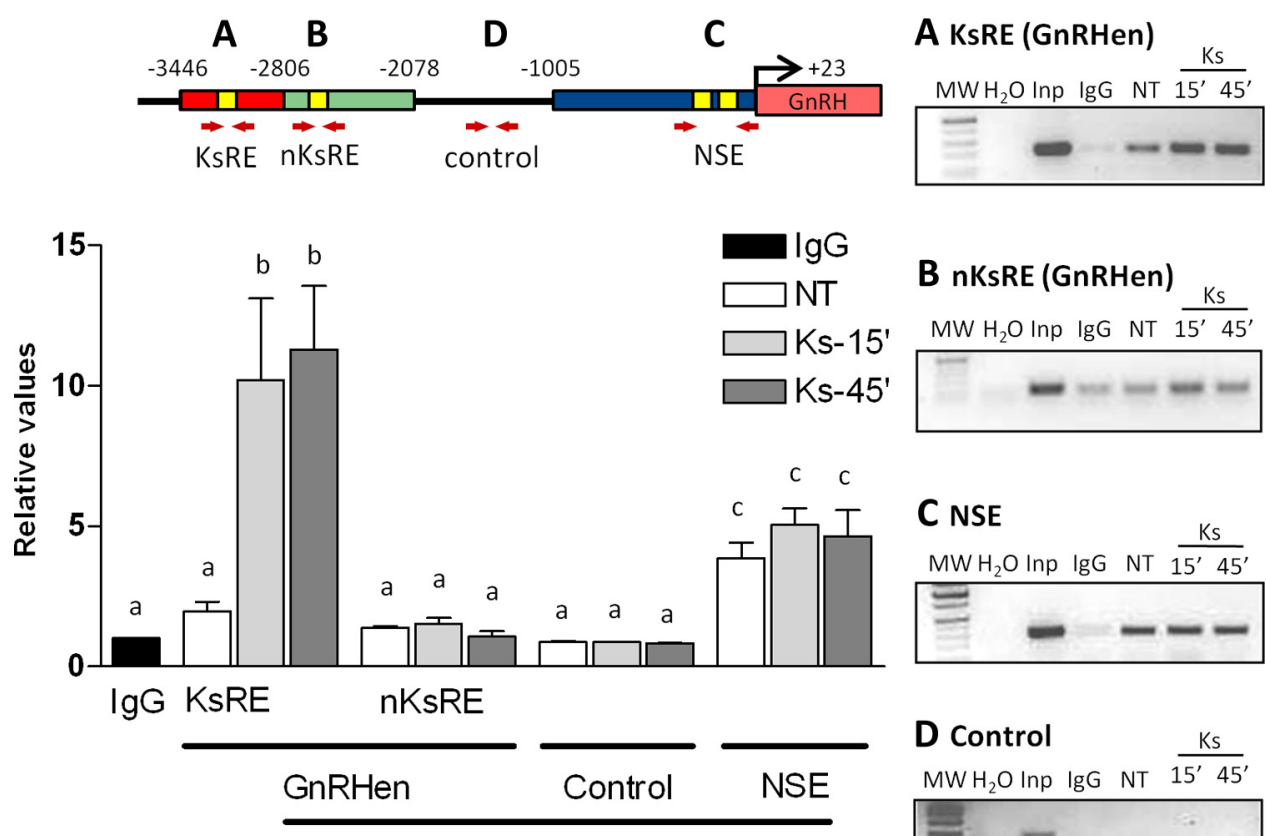

B nKsRE (GnRHen)

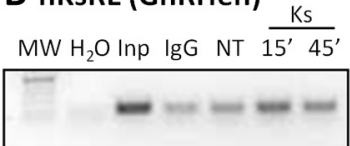

\section{NSE}

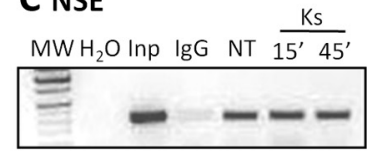

$\mathrm{GnRH}$

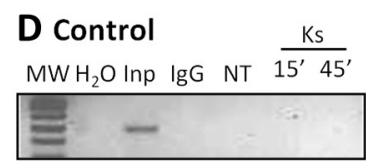

Figure 4. ChIP in GT1-7 cells followed by qPCR. Kiss induces binding of Otx-2 to the KsRE in the mGnRH promoter in GT1-7 cells. The 0tx-2 binding sites are shown in the model representation (yellow boxes). Red arrows represent the primer's localization used in the $\mathrm{PPCR}$ analysis. $\boldsymbol{A}, 0 \mathrm{Otx}$-2 binding site in the KsRE contained between -3005 and $-3000 \mathrm{bp}$ on the mGnRH promoter (yellow box in the red shading). $\boldsymbol{B}$, Otx-2 binding site contained between - 2418 and - 2413 bp on the mGnRH promoter located in the GnRH enhancer (nKsRE; yellow box in the green shading). C, Otx-2 binding site contained in the NSE (yellow bow in the blue shading). $\boldsymbol{D}$, Negative binding control in the GnRH promoter within -1858 and $-1567 \mathrm{bp}$ (black line). Graphic representation of the means \pm SE of relative DNA (qRT-PCR) graphed as fold increase of levels relative to $\lg \mathrm{G}$ group (black column). Cells were treated with $10^{-9} \mathrm{M}$ Kiss for 15 and $45 \mathrm{~min}(n=3, p \leq 0.05)$. There is no statistical difference between groups with the same letters.

tive and inactive promoters in GT1-7 cells, respectively (Iyer et al., 2011). Initially, semiquantitative PCR products corresponding to GnRH regulatory elements were compared in $1 \%$ agarose gels (Fig. 3, right); however, qRT-PCR was chosen to increase the sensitivity of detection. FAIRE detected nucleosome-depleted DNA at the Otx-2 binding site located in the KsRE ( -3446 to $-2806 \mathrm{bp}$ ) in the nontreated group with the same levels as the $\beta$-actin gene (active promoter) and increased by proximally sixfold after 15 and 45 min of Kiss treatment $(n=3-4, p \leq 0.05$; Fig. $3 A$, graph). A small amount of nucleosome-depleted DNA at the Otx-2 binding site located in the non-KsRE (between -2806 to -2078 bp) was observed when compared with the FSH- $\beta$ negative control, but no changes were observed after Kiss treatment $(n=3-4, p \geq 0.05 ;$ Fig. 3B). Furthermore, FAIRE performed at 
the Otx- 2 binding sites located in the NSE $(-1005$ to $+23 \mathrm{bp})$ demonstrated that the chromatin is active with no effect noted after kisspeptin treatment in GT1-7 ( $n=3-4, p \geq$ 0.05 ; Fig. $3 D$, graph). In addition, there was no evidence of active chromatin in areas between -1858 and -1567 bp of the mGnRH promoter, which was used as inactive control elements in this promoter (Fig. 3C). FAIRE detected nucleosome-depleted DNA from the $\beta$-actin promoter gene and no changes were observed after Kiss treatment. As expected, no active FSH- $\beta$ promoter elements were detected in these cells.

The KsRE is located in the GnRHen and contains an Otx-2 binding site

Our data demonstrated the presence of a KsRE located between -3446 and -2806 bp on the mGnRHen element in GnRHsecreting neuronal cell lines and in $\mathrm{GnRH}$ LUC transgenic mice, defining the $\mathrm{mGnR}$ Hen in two specific regions. The elements contained within -2806 and -2078 bp of the GnRHen are nKsRE. This suggests that the sequences necessary to mediate the Kiss effects in neuronal $\mathrm{mGnRH}$ expression are contained between -3446 and -2806 bp of the GnRHen. These elements were examined for sequences sharing homology with binding sites for the Otx- 2 homeodomain protein. The analysis of the GnRH promoter using the DNADynamo software revealed two Otx-2 binding sites located in the GnRHen element, which were not previously described: one between -3005 and -3000 bp (GGATTA) and the second between -2418 to -2413 bp of the $\mathrm{mGnRH}$ promoter (GATAA). Interestingly, the KsRE we described functionally contains the former binding site, which had previously been shown to bind Otx-2 with high affinity (Briata et al., 1999; Kim et al., 2007). The alignment of the mouse, rat, and human GnRH promoter sequences revealed a high degree of conservation at the Otx- 2 site in the KsRE. The Otx-2 sequence motif located from -3005 to -3000 in the mouse gene has $83 \%$ homology to the rat sequence (located from -2540 to -2535 ), while the comparative region of homology between mouse and human has 100\% homology (located from -3665 to -3660 in the human gene; data not shown).

\section{Kiss increases binding of Otx-2 to the KsRE in the mGnRH promoter}

To evaluate the binding of Otx-2 to the KsRE ( -3005 to -3000 $\mathrm{bp})$, to the nKsRE in the GnRHen $(-2418$ to $-2413 \mathrm{bp})$ and to the NSE ( -356 to -249 bp), we performed ChIP in GT1-7 cells followed by qRT-PCR using primers specific to these regulatory elements (Fig. 4; Table 1). Initially, semiquantitative PCR products corresponding to $\mathrm{GnRH}$ regulatory elements were compared in $1 \%$ agarose gels (Fig. 4 , right); however, qRT-PCR was chosen to increase the sensitivity of detection. Cells treated with $10^{-9} \mathrm{M}$ Kiss for 15 and 45 min were compared with an NT group. Otx-2 binding to the KsRE increased by $>5$-fold in cells treated with Kiss when compared with the NT cells $(n=3, p \leq 0.05$; Fig. $4 A$, graph). There was no significant difference in binding between 15 and $45 \mathrm{~min}$ of treatment. Kiss treatment had no effect on Otx-2 binding to the cis-element defined as nKsRE in the GnRHen ( $n=$ $3, p \geq 0.05$; Fig. $4 B$, graph). Interestingly, no changes in the binding of Otx-2 after Kiss treatment were observed within the Otx-2 binding site previously described in the NSE, located between -356 and -249 bp of the GnRH promoter $(n=3, p \geq$ 0.05; Fig. $4 C$, graph). Since there are no known Otx-2 binding sites between -1858 and -1567 bp of the promoter, this region was used as an Otx-2-negative binding control, and indeed ChIP analysis did not reveal binding of Otx-2 within this area (Fig. 4D, graph). The qRT-PCR was also performed on input sample dilutions to test the efficiency primers and produce a standard curve for calculating the fold enrichment. A sample immunoprecipitated by IgG antibody was used as negative control of the IP process.

\section{Otx-2 mRNA expression is increased by Kiss in GT1-7 and \\ GN11 cells}

qRT-PCR was used to evaluate changes in Otx-2 mRNA obtained from both cell lines treated with $10^{-9} \mathrm{M}$ Kiss for 1, 2, and $4 \mathrm{~h}$. In GT1-7 cells, $10^{-9} \mathrm{M}$ Kiss produced an $\sim 2$-fold increase in Otx-2 mRNA levels after $2 \mathrm{~h}$ of treatment that continued through $4 \mathrm{~h}$ 


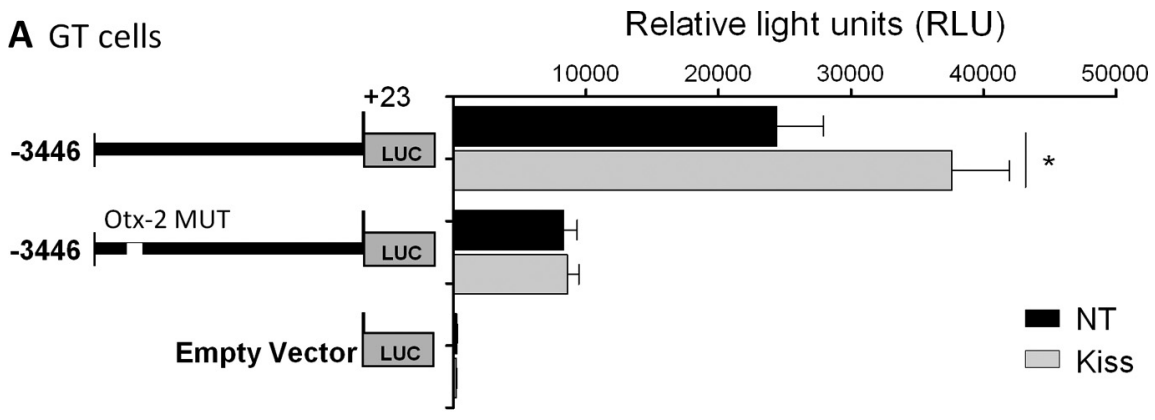

B GN cells

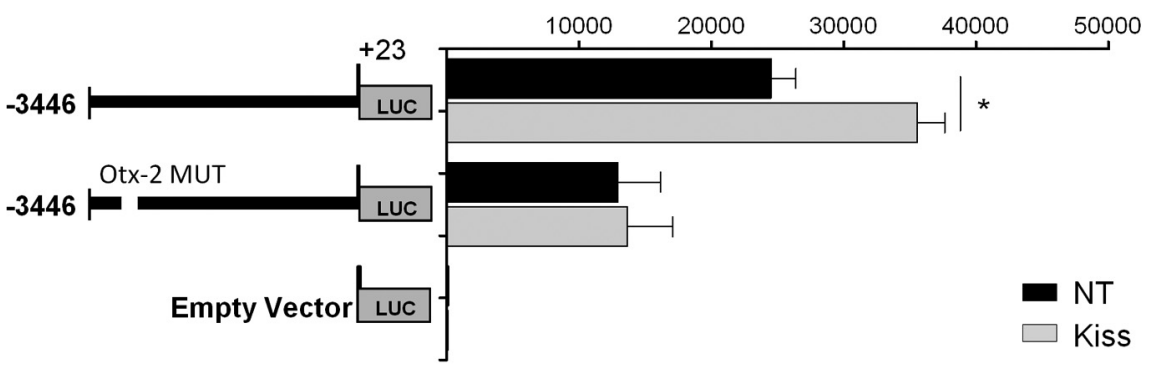

\section{Hypothalamic GnRH mRNA}

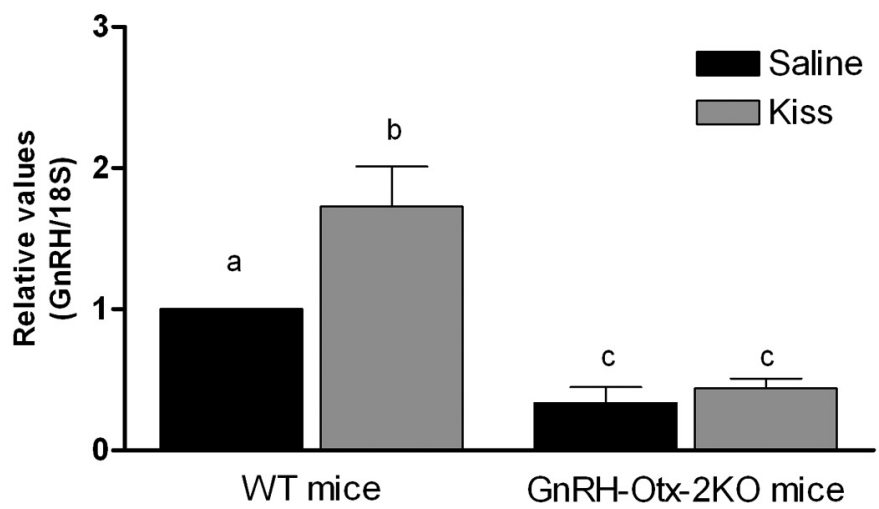

Figure 6. LUC expression in GT1-7 ( $\boldsymbol{A})$ and GN11 ( $\boldsymbol{B})$ cell lines transfected with $-3446 /+23$ bp mGnRH promoter and the $-3446 /$ +23 mGnRH promoter containing the mutated $-3005 /-30000$ tx-2 binding site $(-3446 /+23$ bp mGnRH Otx-2 Mut) fused to the LUC reporter gene. LUC expression was measured as RLUs in NT cells and treated with $10^{-9} \mathrm{M}$ Kiss for $4 \mathrm{~h}(n=3-4, p \leq 0.05)$. Asterisks indicate significant differences. C, Hypothalamic GnRH mRNA expression modulated by Kiss in wild-type and GnRH-Otx-2KO mice (qRT$P(R)$. Graphic representation of the means \pm SE of relative mRNA graphed as fold increase of levels relative to wild-type (WT) group treated with saline. Mice were injected with saline or $1 \mathrm{nmol}$ Kiss and hypothalamus harvested after 20 min of injection $(n=3-4, p \leq 0.05)$. There is no statistical difference between groups with the same letters.

with an $\sim 3$-fold increase ( $n=3, p \leq 0.05$; Fig. $5 A$ ). In gonadotropin cells, $10^{-9} \mathrm{M}$ Kiss produced an $\sim 2.5$-fold increase in Otx-2 mRNA levels after $2 \mathrm{~h}$ of treatment that continued through $4 \mathrm{~h}$ by approximately a threefold increase $(n=3-4, p \leq 0.05$; Fig. $5 A)$. In agreement with previous studies, Otx- 2 mRNA expression was expressed to a lesser extent in GN11 cells than in GT1-7 cells.

\section{Otx-2 protein expression is increased by Kiss in GT1-7 and GN11 cells}

To further evaluate the Otx-2 TF involvement in GnRH promoter activation by Kiss, GT1-7 and GN11 cells were incubated at different times $(0.5,1,2,3$, and $4 \mathrm{~h})$ with $10^{-9} \mathrm{M}$ Kiss, and expression of Otx-2 protein was measured by Western blot analysis (Fig. $5 B, C$ ). In both cell lines, Otx-2 was increased in a timedependent fashion from 30 min of treatment through $4 \mathrm{~h}(n=3$; Fig. 5A,B). However, GT1-7 showed a faster response to Kiss treatment, reaching the maximal twofold increase at $1 \mathrm{~h}$ after treatment $(n=3, p \leq$ 0.05 ; Fig. $5 B$ ) since GN11 cells did reach the maximal twofold increase after $2 \mathrm{~h}$ of treatment $(n=3, p \leq 0.05$; Fig. $5 C)$. No significant changes in the total protein levels of $\beta$-actin were identified.

Kisspeptin was unable to increase LUC activity in GN11 and GT1-7 cells containing a mutated Otx-2 binding site within the KsRE

GT1-7 and GN11 cells were transfected with the mGnRH promoter containing a mutated Otx-2 binding site in the KsRE located between -3005 and $-3000 \mathrm{bp}$ of the mGnRH promoter fused to the luciferase reporter gene. After transfection, cells were treated with $10^{-9} \mathrm{M}$ Kiss for $4 \mathrm{~h}$. In GT1-7 and GN11 cells, no changes in LUC activities were observed after Kiss treatment; in contrast to the previous experiments using the $-3446 /+23$ bp of the mGnRH promoter $(n=3-4, p \leq 0.05$; Fig. $6 A, B)$.

\section{Kisspeptin was unable to increase hypothalamic GnRH mRNA expression in GnRH-Otx-2KO mice \\ GnRH mRNA levels were measured by qRT-PCR in hypothalamic tissue of control and GnRH-Otx-2KO mice. In wild-type mice, $1 \mathrm{nmol}$ Kiss treatment produced an $\sim 2$-fold increase in hypothalamic GnRH mRNA levels $(n=4, p \leq 0.05$; Fig. $6 C)$. Consistent with the in vitro mutagenesis studies, no changes in hypothalamic GnRH expression were observed after Kiss treat- ment in GnRH-Otx-2KO animals $(n=3$, $p \leq 0.05$; Fig. $6 C$ ).}

\section{Discussion}

Evidence for a direct role of Kiss at the level of the GnRH neuron comes from in vivo anatomical studies (Han et al., 2005; Gottsch et al., 2006; Kauffman et al., 2007; Caraty and Franceschini, 2008; Roa et al., 2008a; Xu et al., 2011) and in vitro experiments performed in GnRH-expressing cell lines (Jacobi et al., 2007; Novaira et al., 2009). However, the molecular basis of GnRH regulation by Kiss remains unclear and thus requires further definition.

Using mouse-derived immortalized GnRH-secreting neuronal cell lines and transgenic mouse models, we investigate the role of Kiss in modulating GnRH transcription/translation activity. These studies provide in vitro and in vivo evidence that the region between -3446 to $-2806 \mathrm{bp}$ of the $\mathrm{mGnRH}$ gene is involved in the regulation of hypothalamic GnRH by Kiss, and that binding of the homeodomain TF, Otx-2, mediates this activation.

Although Kiss regulation of GnRH secretion is strongly supported by data from several manuscripts, its role on GnRH gene expression has more recently been elucidated. In fact, based on the use of inhibitors of transcription and translation in a $\mathrm{GnRH}$ 


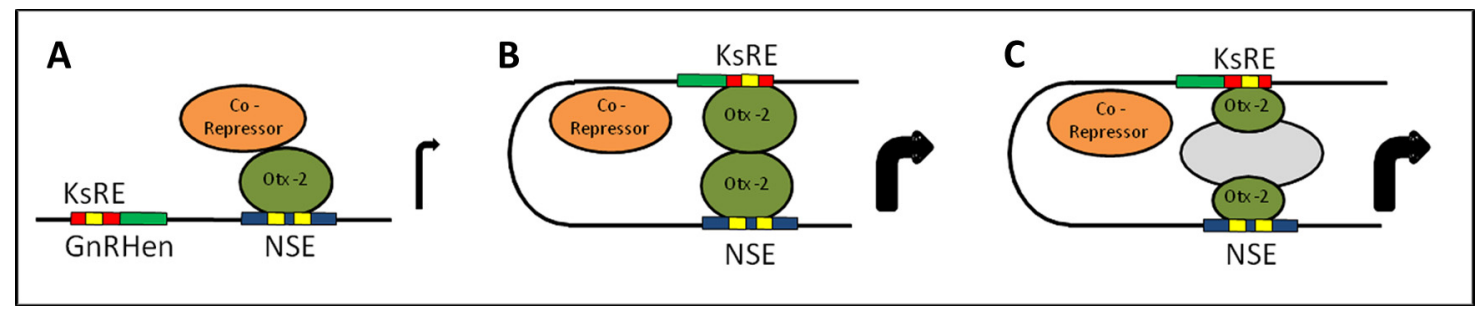

Figure 7. Model of potential molecular mechanisms for activation of GnRH transcription in GnRH neuron stimulated by Kiss. The potential interactions between the KsRE (red box), Otx-2 binding sites at the KsRE and the NSE (yellow boxes), and the 0tx-2 transcription factor (dark green) are shown in $\boldsymbol{B}$ (direct 0tx-2/0tx-2 interaction) and $\boldsymbol{C}$ (via unidentified bridging proteins, gray). These interactions ( $\boldsymbol{B}$ or $\boldsymbol{C}$ ) may exclude corepressors (in orange) such as groucho (Gro) proteins from binding to 0 tx-2 $(\boldsymbol{A})$ to increase $\mathrm{GnRH}$ transcription.

neuronal cell line, Pitts et al., 2001 suggested that cyclic GnRH synthesis was not necessary for pulse generation, while other studies have suggested that GnRH synthesis and secretion are closely coupled (Vazquez-Martinez et al., 2002; Leclerc and Boockfor, 2005; Leclerc et al., 2008; Novaira et al., 2009). These studies, including those from our laboratory, showed that Kiss increases GnRH mRNA levels (Jacobi et al., 2007; Novaira et al., 2009). Hence, it is most likely that Kiss affects GnRH expression at both the secretory and pretranslational level to influence the onset of puberty and reproductive function.

Although GnRH mRNA was shown to increase in response to Kiss treatment in GnRH neuronal cell lines, the specific regions of the $\mathrm{mGnRH}$ promoter, TFs, and chromatin modifications that mediate Kiss action on GnRH gene expression were unknown. Hence, the goal was to use neuronal cell lines and transgenic mice to define the effect of Kiss. The GnRH promoter has previously been characterized in in vitro studies in conjunction with in vivo mapping using transgenic GnRH promoter reporter mice, to identify an NSE as well as enhancer element (GnRHen) important for neuronal GnRH gene expression (Eraly et al., 1998; Wolfe et al., 2002; Kim et al., 2007). Also, previous studies have described the important interaction between the NSE and the GnRHen in gene activation (Nelson et al., 2000). As previously shown, the GnRH promoter fragment $(-3446$ to $+23 \mathrm{bp})$ appears to contain all the elements needed for normal expression and regulation. In vitro, the Kiss effect on $\mathrm{GnRH}$ gene transcription was measured and a KsRE was localized. GT1-7 and GN11 cells transfected with sequential deletions of the $\mathrm{mGnRH}$ promoter fused to the LUC reporter gene identified a KsRE located within the region between -3446 to -2806 bp of the $\mathrm{mGnRH}$ promoter. Despite the insight gained from in vitro studies, cell culture is unlikely to reflect intricate signaling pathways regulating GnRH gene expression in vivo. Therefore, we have developed transgenic mice containing a series of $\mathrm{GnRH}$ promoter deletion constructs fused to reporter genes to study the regulation of the $\mathrm{GnRH}$ gene. In our in vivo studies, we were able to corroborate the presence of a KsRE located in the same region we described in cultured neuronal cell lines, within the region between -3446 to $-2806 \mathrm{bp}$ of the mGnRH promoter. Thus, the GnRHen is now functionally divided into two elements, the elements contained between -2806 and -2078 bp on the GnRHen are nKsRE responsive, while the sequences necessary to mediate the Kiss effects on neuronal $\mathrm{mGnRH}$ expression are contained between -3446 and -2806 bp of the GnRHen.

In order for transcription to proceed, modulation of chromatin structure is required. Inactive genes usually display condensed chromatin, while active genes and regulatory elements are often in an open chromatin conformation to facilitate binding of regulatory proteins (Sims et al., 2003; Kouzarides, 2007; Li et al., 2007). To determine whether $\mathrm{GnRH}$ is subject to this modulation by Kiss was the goal of the next series of experiments. Two recent manuscripts had suggested that GnRH expression may be modulated by changes in chromatin structure and histone modifications (Kurian et al., 2010; Iyer et al., 2011). Thus, we hypothesized that chromatin dynamics would then be regulated by the kisspeptinGPR54 system. Genomic isolation of active regulatory elements (nucleosome-depleted DNA) was performed in GnRH neuronal cell lines treated with Kiss. Kisspeptin induced an active conformation of chromatin in the GnRH promoter within the KsRE (located between -3446 and -2806 bp upstream from the transcription start site). No changes of nucleosome-depleted DNA were observed within the GnRHen in the nKsRE (located between -2806 and -2078 bp) and in the NSE. Our results add to the growing body of evidence that the $\mathrm{GnRH}$ gene is a target of Kiss regulation.

Follow-up studies to identify the intranuclear messengers that mediate GPR54 signaling in the GnRH promoter were performed. Sequence analysis of the KsRE revealed two Otx- 2 binding sites previously unidentified in these areas of the $\mathrm{mGnRH}$ promoter. The former is located between -3005 and $-3000 \mathrm{bp}$ (TAATCC) of the $\mathrm{mGnRH}$ promoter, which sequences had previously been shown located at the NSE and bind with high affinity to Otx-2 (Kim et al., 2007). The second Otx-2 binding site is located between -2417 to -2413 bp (TTATC), and these sequences were also described previously present in the NSE and shown to bind with low affinity to Otx-2 (Kim et al., 2007). Double-label immunohistochemistry has colocalized Otx-2 homeoprotein in GnRH neurons in mice (Mallamaci et al., 1996). Furthermore, Otx-2 has been identified and was found to be necessary for expression of the GnRH gene (Kelley et al., 2000). Elimination of Otx-2 binding sites in transgenic mice containing the proximal $356 \mathrm{bp}$ fragment of the $\mathrm{mGnRH}$ promoter resulted in low hypothalamic luciferase expression, thus highlighting the important role of Otx-2 in neuronal tissue-specific expression of the mGnRH gene (Kim et al., 2007). In addition, deletion of Otx-2 in GnRH neurons results in a significant decrease in the number of $\mathrm{GnRH}$ neurons in the hypothalamus, low levels of $\mathrm{GnRH}$, delay in pubertal onset, abnormal estrous cyclicity, and infertility in the GnRH neuron-specific Otx-2 KO (GnRHOtx2KO) mice (Diaczok et al., 2011). Together, these data provide in vivo evidence that Otx-2 is critical for GnRH expression and reproductive competence. The GnRH-Otx2KO mice, albeit having $~ 80 \%$ fewer GnRH neurons in the hypothalamus than wild-type mice, were unable to increase GnRH mRNA expression after Kiss treatment, reinforcing the role of Otx-2 in Kiss signaling. Furthermore, Kiss increased Otx-2 mRNA and protein in the GnRH-expressing cell lines, and our results suggest that this newly described Otx-2 binding site is conserved across vertebrates.

In our studies, to assess the role of Otx-2 binding to the $\mathrm{GnRH}$ promoter in response to Kiss in the control of GnRH gene expres- 
sion, changes in Otx-2 binding to defined elements were evaluated. Otx-2 binding to the KsRE was significantly increased in cells treated with Kiss. However, Otx-2 occupancy on the consensus element in the NSE located between -356 and -249 bp of the $\mathrm{mGnRH}$ promoter was present but unchanged after Kiss treatment. These findings may be explained by nucleosome-depleted DNA levels observed in the NSE, which were present; however, none changed after kiss treatment in GT1-7 cells, suggesting the important role of Otx-2 in cell-specific gene expression. Additional studies documented the critical role of Otx-2 binding to the KsRE to mediate increases in GnRH promoter activity in response to Kiss. In vitro, transient transfection studies showed that Kiss was unable to activate expression from an Otx-2 binding site in the KsRE that was mutated.

Our previously published studies showed that phosphorylation of both mitogen-activated protein kinase (MAPK) and the phosphatidylinositol-3 kinase/Akt (PI3K/Akt) substrates are downstream targets of GPR54 activation by Kiss, regulating GnRH expression in GT1-7 and GN11 cell lines (Novaira et al., 2009). In addition, MAPK and PI3K/Akt pathways were shown to upregulate expression of several TFs including Otx-2 in Xenopus embryonic cells (Pera et al., 2001, 2003). Furthermore, it was recently shown that histone deacetylases (HDACs) regulate GnRH-1 gene expression via modulating Otx-2-driven transcriptional activity (Gan et al., 2012), suggesting a possible GPR54 signaling pathways to modulate $\mathrm{GnRH}$ expression in GnRH neurons.

Two models illustrating potential interactions between the Otx-2 TF, the KsRE, and the Otx-2 binding sites are shown in Figure 7. Direct Otx-2/Otx-2 interaction or interactions via unidentified bridging proteins may exclude corepressors such as groucho (Gro) proteins (Malin et al., 2005; Rave-Harel et al., 2005; Larder and Mellon, 2009) from binding to Otx-2 increasing GnRH transcription. We postulate that such mechanisms would permit GnRH synthesis to remain coupled to GnRH secretion in response to Kiss.

In conclusion, these studies demonstrate the ability of Kiss to modify chromatin conformation and increase Otx-2 binding to a KsRE. This may be a mechanism to increase GnRH expression in response to Kiss during pubertal onset and reproductive cycling. Dysfunction of this critical pathway may explain pubertal disorders and mammalian infertility. This pathway may thus serve as a therapeutic target in humans.

\section{References}

Briata P, Ilengo C, Bobola N, Corte G (1999) Binding properties of the human homeodomain protein OTX2 to a DNA target sequence. FEBS Lett 445:160-164. CrossRef Medline

Bustin SA, Benes V, Nolan T, Pfaffl MW (2005) Quantitative real-time RTPCR-a perspective. J Mol Endocrinol 34:597-601. CrossRef Medline

Caraty A, Franceschini I (2008) Basic aspects of the control of GnRH and LH secretions by kisspeptin: potential applications for better control of fertility in females. Reprod Domest Anim 43 [Suppl 2]:172-178.18638120

Coss D, Jacobs SB, Bender CE, Mellon PL (2004) A novel AP-1 site is critical for maximal induction of the follicle-stimulating hormone beta gene by gonadotropin-releasing hormone. J Biol Chem 279:152-162. Medline

de Roux N, Genin E, Carel JC, Matsuda F, Chaussain JL, Milgrom E (2003) Hypogonadotropic hypogonadism due to loss of function of the KiSS1derived peptide receptor GPR54. Proc Natl Acad Sci U S A 100:1097210976. CrossRef Medline

Diaczok D, Romero C, Zunich J, Marshall I, Radovick S (2008) A novel dominant negative mutation of OTX2 associated with combined pituitary hormone deficiency. J Clin Endocrinol Metab 93:4351-4359. CrossRef Medline

Diaczok D, DiVall S, Matsuo I, Wondisford FE, Wolfe AM, Radovick S (2011) Deletion of Otx2 in GnRH neurons results in a mouse model of hypogonadotropic hypogonadism. Mol Endocrinol 25:833-846. CrossRef Medline

Dungan HM, Clifton DK, Steiner RA (2006) Minireview: kisspeptin neurons as central processors in the regulation of gonadotropin-releasing hormone secretion. Endocrinology 147:1154-1158. Medline

Eraly SA, Nelson SB, Huang KM, Mellon PL (1998) Oct-1 binds promoter elements required for transcription of the GnRH gene. Mol Endocrinol 12:469-481. CrossRef Medline

Gan L, Ni PY, Ge Y, Xiao YF, Sun CY, Deng L, Zhang W, Wu SS, Liu Y, Jiang W, Xin HB (2012) Histone deacetylases regulate gonadotropinreleasing hormone i gene expression via modulating Otx2-driven transcriptional activity. PLoS One 7:e39770. CrossRef Medline

Giresi PG, Lieb JD (2009) Isolation of active regulatory elements from eukaryotic chromatin using FAIRE (Formaldehyde Assisted Isolation of Regulatory Elements). Methods 48:233-239. CrossRef Medline

Gottsch ML, Clifton DK, Steiner RA (2006) Kisspepeptin-GPR54 signaling in the neuroendocrine reproductive axis. Mol Cell Endocrinol 254- 255: 91-96. CrossRef

Han SK, Gottsch ML, Lee KJ, Popa SM, Smith JT, Jakawich SK, Clifton DK, Steiner RA, Herbison AE (2005) Activation of gonadotropin-releasing hormone neurons by kisspeptin as a neuroendocrine switch for the onset of puberty. J Neurosci 25:11349-11356. CrossRef Medline

Huh YH, Ryu JH, Chun JS (2007) Regulation of type II collagen expression by histone deacetylase in articular chondrocytes. J Biol Chem 282:1712317131. CrossRef Medline

Iyer AK, Brayman MJ, Mellon PL (2011) Dynamic chromatin modifications control GnRH gene expression during neuronal differentiation and protein kinase C signal transduction. Mol Endocrinol 25:460-473. CrossRef Medline

Jacobi JS, Martin C, Nava G, Jeziorski MC, Clapp C, Martínez de la Escalera G (2007) 17-Beta-estradiol directly regulates the expression of adrenergic receptors and kisspeptin/GPR54 system in GT1-7 GnRH neurons. Neuroendocrinology 86:260-269. CrossRef Medline

Kauffman AS, Clifton DK, Steiner RA (2007) Emerging ideas about kisspeptin- GPR54 signaling in the neuroendocrine regulation of reproduction. Trends Neurosci 30:504-511. CrossRef Medline

Kelley CG, Lavorgna G, Clark ME, Boncinelli E, Mellon PL (2000) The Otx2 homeoprotein regulates expression from the gonadotropin-releasing hormone proximal promoter. Mol Endocrinol 14:1246-1256. CrossRef Medline

Kim HH, Wolfe A, Smith GR, Tobet SA, Radovick S (2002) Promoter sequences targeting tissue-specific gene expression of hypothalamic and ovarian gonadotropin-releasing hormone in vivo. J Biol Chem 277:51945202. CrossRef Medline

Kim HH, Wolfe A, Cohen RN, Eames SC, Johnson AL, Wieland CN, Radovick S (2007) In vivo identification of a 107-base pair promoter element mediating neuron-specific expression of mouse gonadotropin-releasing hormone. Mol Endocrinol 21:457-471. Medline

Kouzarides T (2007) Chromatin modifications and their function. Cell 128: 693-705. CrossRef Medline

Kurian JR, Keen KL, Terasawa E (2010) Epigenetic changes coincide with in vitro primate GnRH neuronal maturation. Endocrinology 151:53595368. CrossRef Medline

Lapatto R, Pallais JC, Zhang D, Chan YM, Mahan A, Cerrato F, Le WW, Hoffman GE, Seminara SB (2007) Kiss1-/- mice exhibit more variable hypogonadism than Gpr54-/- mice. Endocrinology 148:4927-4936. CrossRef Medline

Larder R, Mellon PL (2009) Otx2 induction of the gonadotropin-releasing hormone promoter is modulated by direct interactions with Grg corepressors. J Biol Chem 284:16966-16978. CrossRef Medline

Leclerc GM, Bose SK, Boockfor FR (2008) Specific GATA-binding elements in the GnRH promoter are required for gene expression pulse activity: role of GATA-4 and GATA-5 in this intermittent process. Neuroendocrinology 88:1-16. CrossRef Medline

Leclerc GM, Boockfor FR (2005) Identification of a novel OCT1 binding site that is necessary for the elaboration of pulses of rat $\mathrm{GnRH}$ promoter activity. Mol Cell Endocrinol 245:86-92. CrossRef Medline

Li B, Carey M, Workman JL (2007) The role of chromatin during transcription. Cell 128:707-719. CrossRef Medline

Malin S, Linderson Y, Almqvist J, Ernberg I, Tallone T, Pettersson S (2005) DNA-dependent conversion of Oct-1 and Oct-2 into transcriptional re- 
pressors by Groucho/TLE. Nucleic Acids Res 33:4618-4625. CrossRef Medline

Mallamaci A, Di Blas E, Briata P, Boncinelli E, Corte G (1996) OTX2 homeoprotein in the developing central nervous system and migratory cells of the olfactory area. Mech Dev 58:165-178. CrossRef Medline

Maxwell IH, Harrison GS, Wood WM, Maxwell F (1989) A DNA cassette containing a trimerized SV40 polyadenylation signal which efficiently blocks spurious plasmid-initiated transcription. BioTechniques 7:276280. Medline

Mellon PL, Windle JJ, Goldsmith PC, Padula CA, Roberts JL, Weiner RI (1990) Immortalization of hypothalamic GnRH neurons by genetically targeted tumorigenesis. Neuron 5:1-10. CrossRef Medline

Navarro VM, Castellano JM, Fernández-Fernández R, Tovar S, Roa J, Mayen A, Nogueiras R, Vazquez MJ, Barreiro ML, Magni P, Aguilar E, Dieguez C, Pinilla L, Tena-Sempere M (2005) Characterization of the potent luteinizing hormone-releasing activity of KiSS-1 peptide, the natural ligand of GPR54. Endocrinology 146:156-163. Medline

Nelson SB, Lawson MA, Kelley CG, Mellon PL (2000) Neuron-specific expression of the rat gonadotropin-releasing hormone gene is conferred by interactions of a defined promoter element with the enhancer in GT1-7 cells. Mol Endocrinol 14:1509-1522. CrossRef Medline

Novaira HJ, Ng Y, Wolfe A, Radovick S (2009) Kisspeptin increases GnRH mRNA expression and secretion in GnRH secreting neuronal cell lines. Mol Cell Endocrinol 311:126-134. CrossRef Medline

Novaira HJ, Yates M, Diaczok D, Kim H, Wolfe A, Radovick S (2011) The gonadotropin-releasing hormone cell-specific element is required for normal puberty and estrous cyclicity. J Neurosci 31:3336-3343. CrossRef Medline

Pera EM, Ikeda A, Eivers E, De Robertis EM (2003) Integration of IGF, FGF, and anti-BMP signals via Smad1 phosphorylation in neural induction. Genes Dev 17:3023-3028. CrossRef Medline

Pera EM, Wessely O, Li SY, De Robertis EM (2001) Neural and head induction by insulin-like growth factor signals. Dev Cell 1:655-665. CrossRef Medline

Pielecka-Fortuna J, Chu Z, Moenter SM (2008) Kisspeptin acts directly and indirectly to increase gonadotropin-releasing hormone neuron activity and its effects are modulated by estradiol. Endocrinology 149:1979-1986. CrossRef Medline

Pitts GR, Nunemaker CS, Moenter SM (2001) Cycles of transcription and translation do not comprise the gonadotropin-releasing hormone pulse generator in GT1 cells. Endocrinology 142:1858-1864. CrossRef Medline

Radovick S, Wray S, Lee E, Nicols DK, Nakayama Y, Weintraub BD, Westphal H, Cutler GB Jr, Wondisford FE (1991) Migratory arrest of gonadotropinreleasing hormone neurons in transgenic mice. Proc Natl Acad Sci U S A 88:3402-3406. CrossRef Medline

Rave-Harel N, Miller NL, Givens ML, Mellon PL (2005) The Grouchorelated gene family regulates the gonadotropin-releasing hormone gene through interaction with the homeodomain proteins MSX1 and OCT1. J Biol Chem 280:30975-30983. CrossRef Medline

Roa J, Aguilar E, Dieguez C, Pinilla L, Tena-Sempere M (2008a) New fron- tiers in kisspeptin/GPR54 physiology as fundamental gatekeepers of reproductive function. Front Neuroendocrinol 29:48-69. CrossRef Medline

Roa J, Vigo E, Castellano JM, Gaytan F, Navarro VM, Aguilar E, Dijcks FA, Ederveen AG, Pinilla L, van Noort PI, Tena-Sempere M (2008b) Opposite roles of estrogen receptor (ER)-alpha and ERbeta in the modulation of luteinizing hormone responses to kisspeptin in the female rat: implications for the generation of the preovulatory surge. Endocrinology 149: 1627-1637. CrossRef Medline

Seminara SB, Messager S, Chatzidaki EE, Thresher RR, Acierno JS Jr, Shagoury JK, Bo-Abbas Y, Kuohung W, Schwinof KM, Hendrick AG, Zahn D, Dixon J, Kaiser UB, Slaugenhaupt SA, Gusella JF, O’Rahilly S, Carlton MB, Crowley WF Jr, Aparicio SA, Colledge WH (2003) The GPR54 gene as a regulator of puberty. $\mathrm{N}$ Engl J Med 349:1614-1627. CrossRef Medline

Seminara SB, Dipietro MJ, Ramaswamy S, Crowley WF Jr, Plant TM (2006) Continuous human metastin 45-54 infusion desensitizes G proteincoupled receptor 54-induced gonadotropin-releasing hormone release monitored indirectly in the juvenile male Rhesus monkey (Macaca mulatta): a finding with therapeutic implications. Endocrinology 147: 2122-2126. CrossRef Medline

Sims RJ 3rd, Nishioka K, Reinberg D (2003) Histone lysine methylation: a signature for chromatin function. Trends Genet 19:629-639. CrossRef Medline

Tian E, Kimura C, Takeda N, Aizawa S, Matsuo I (2002) Otx2 is required to respond to signals from anterior neural ridge for forebrain specification. Dev Biol 242:204-223. CrossRef Medline

Vazquez-Martinez R, Leclerc GM, Wierman ME, Boockfor FR (2002) Episodic activation of the rat $\mathrm{GnRH}$ promoter: role of the homeoprotein oct-1. Mol Endocrinol 16:2093-2100. CrossRef Medline

Wolfe AM, Wray S, Westphal H, Radovick S (1996) Cell-specific expression of the human gonadotropin-releasing hormone gene in transgenic animals. J Biol Chem 271:20018-20023. CrossRef Medline

Wolfe A, Kim HH, Tobet S, Stafford DE, Radovick S (2002) Identification of a discrete promoter region of the human GnRH gene that is sufficient for directing neuron-specific expression: a role for POU homeodomain transcription factors. Mol Endocrinol 16:435-449. CrossRef Medline

Wolfe A, Divall S, Singh SP, Nikrodhanond AA, Baria AT, Le WW, Hoffman GE, Radovick S (2008) Temporal and spatial regulation of CRE recombinase expression in gonadotrophin-releasing hormone neurones in the mouse. J Neuroendocrinol 20:909-916. CrossRef Medline

Wong ML, Medrano JF (2005) Real-time PCR for mRNA quantitation. BioTechniques 39:75-85. CrossRef Medline

Wood WM, Kao MY, Gordon DF, Ridgway EC (1989) Thyroid hormone regulates the mouse thyrotropin beta-subunit gene promoter in transfected primary thyrotropes. J Biol Chem 264:14840-14847. Medline

Xu Z, Kaga S, Tsubomizu J, Fujisaki J, Mochiduki A, Sakai T, Tsukamura H, Maeda K, Inoue K, Adachi AA (2011) Circadian transcriptional factor DBP regulates expression of Kiss1 in the anteroventral periventricular nucleus. Mol Cell Endocrinol 339:90-97. CrossRef Medline 